\title{
Los lugares de la memoria en América Latina*
}

Fecha de entrega: 04 abril de 2020

Fecha de evaluación: 10 abril de 2020

Fecha de aprobación: 20 abril de 2020

\author{
Juliana Paola Díaz Quintero**
}

\section{Resumen}

Se propone una reflexión filosófica sobre el imperativo ético y político de pensar y reconstruir nuestro pasado a partir de la experiencia del sujeto latinoamericano oprimido y resistente. En este orden de ideas, el objetivo principal del artículo es emprender una búsqueda de aquellos lugares en los que habitan y se conservan en el tiempo las memorias de los latino-americanos antes y después del proceso de colonización o de "invasión" de la Modernidad europea. Esta indagación se inclina específicamente hacia esas memorias "no oficiales", construidas desde las comunidades en sus prácticas culturales, que mediante la rememoración y la tradición oral crearon vínculos de resistencia contra el olvido, al tiempo que preservaban aspectos fundamentales de sus tradiciones. Así, llamamos lugares a aquellos elementos que albergan fragmentos de lo pretérito invisibilizado por el discurso histórico oficial y que permiten establecer un vínculo trascendente entre pasado y presente,

* Este artículo hace parte del tercer capitulo de mi monografia intitulada: História e memória no pensamento de Walter Benjamin: Marxismo e Messianismo ao serviço da emancipação. Realizada con el apoyo de la Coordinación para la Mejora del Personal de Educación Superior de Brasil (Capes). Código de financiamiento 001. Citar como: Díaz Quintero, J. P. (2020). Los lugares de la memoria en América Latina. Cuadernos de Filosofía Latinoamericana, 41(123), 167-186. Dol: https://doi.org/ $10.15332 / 25005375 / 5992$

* Filósofa egresada de la Universidad del Atlántico, Colombia, miembro del semillero de investigación Amauta del programa de Filosofía de esta misma institución. Magíster en Filosofía de la Universidade Federal de Uberlandia, Brasil. Becada por la OEA y la Capes Brasil en el año 2018 para la realización de la Maestría en Filosofía. Correo electrónico: julianadiazquintero22@gmail.com 
una recreación del pasado que surge a partir de la reconstrucción interpretativa de ruinas, rastros y vestigios de un tiempo que no ha dejado de ser y al que aún es posible acceder y conocer. Posteriormente, se destacan algunos episodios importantes de nuestra historia latinoamericana en los que esas memorias encuentran su lugar.

Palabras clave: memoria, América Latina, lugares, ruinas, tradición oral.

\section{Places of Memory in Latin America}

\section{Abstract}

This article offers a philosophical reflection on the ethical and political imperative of thinking and rebuilding our past on the basis of the experience of the oppressed and resister Latin American subject. Accordingly, the main purpose of the article is to undertake a search for those places where the memories of Latin Americans live and are preserved over time before and after the process of colonization or "invasion" of European Modernity. This inquiry focuses particularly on "unofficial" memories built by the communities by means of their cultural practices. Through remembrance and oral tradition, communities have created bonds of resistance against forgetfulness while preserving fundamental aspects of their traditions. Thus, we call places those elements that hold fragments of the past that has been covered by the official historical discourse and that allow to establish a transcendent bond between past and present: a recreation of the past that arises from the interpretative reconstruction of ruins, traces, and clues of a time that has not ceased to be and that we can still access and know. Finally, we highlight some important episodes of Latin American history in where such memories have found a place.

Keywords: Memory, Latin America, Places, Ruins, Oral Tradition. 
¡Cambiemos la piel! Adoptemos ahora "metódicamente” la del indio, del africano esclavo, del mestizo humillado, del campesino empobrecido, del obrero explotado, del marginal apiñado por millones de miserables de las ciudades latinoamericanas contemporáneas. Tomemos como propios los "ojos" del pueblo oprimido, desde "los de abajo".

ENRIQUE DUSSEL

\section{2, o el nacimiento de la Modernidad en América Latina}

Walter Benjamin elaboró una minuciosa descripción filosófico-cultural de la Modernidad, capaz de revelar una racionalidad que se erigía sobre la falacia desarrollista de la evolución histórica, fundamentada en un ideal de progreso que se forjaba con violencia y que dejaba a su paso cadáveres y ruinas. La joven América Latina padeció en carne propia los orígenes de dicha racionalidad. En la obra de Benjamin, aunque de manera breve, nuestra América ocupa un lugar especial, por lo menos en dos de sus obras: Calle de mano única e Infancia en Berlín. En estos textos el pensador alude a la Ciudad de México y a su cultura ancestral. En 1915, Benjamin asistió en Múnich a los cursos del profesor americanista Walter Lehmann, en que fueron estudiadas las culturas mesoamericanas, el nahualt y los mitos indígenas. Benjamin frecuentaba estos seminarios regularmente, según su gran amigo Scholem:

Comenzó estudios de la cultura mexicana y la religión de los mayas y aztecas, estudios estrechamente vinculados a sus intereses mitológicos. [...] Benjamin se familiarizó con la figura del sacerdote español Bernardo Sahagún, a quien debemos tanto por la preservación de las tradiciones mayas y aztecas. (Scholem, 1975, pp. 42-43)

Luego, en 1928, apareció una breve reseña de la obra biográfica de Marcel Brion sobre Bartolomé de las Casas, publicada en Die Literarische Welt un órgano independiente de la literatura alemana de los años de Weimar. En su reseña, Benjamin es enfático al criticar uno de los genocidios más aberrantes producido por el eurocentrismo de la Modernidad capitalista, como lo evidencia el siguiente pasaje: 
La historia colonialista de los pueblos europeos comienza con el violento evento de la conquista de América, que transformó al mundo nuevamente en una sala de tortura. Los telescopios del soldado español dirigidos a los enormes depósitos de oro y dinero en América han producido un estado espiritual en el que nadie puede pensar sin temblar de horror. (Benjamin, [1928] 2020, p. 180)

Este breve texto sugiere que Benjamin tuvo acceso a aquella parte de la historia de América, escrita desde la perspectiva de los derrotados. "En nombre del cristianismo, un sacerdote se opone a las atrocidades cometidas en nombre del catolicismo", de la misma manera que otro sacerdote, Bernardino de Sahagún, salvó, en su trabajo, la herencia cultural india destruida con las bendiciones del catolicismo (Benjamin, [1928] 2020, pp. 180-181). El otro sacerdote fue Bartolomé de las Casas, figura fundamental de la historia de América Latina y uno de los principales defensores de los pueblos indígenas.

Benjamin finaliza su reseña destacando el trabajo ético y político del padre Sahagún, es decir, el rescate de la memoria y la historia de los oprimidos de nuestra América: "Sahagún rescató con su obra Historia general de las cosas de la nueva España la historia que desapareció bajo el protectorado del catolicismo" (Benjamin, [1928] 2020, pp. 180-181). Aunque sea un texto breve, denota la importancia y la universalidad del método benjaminiano de "cepillar la historia a contrapelo" puesto que, como en el caso de la sufrida América, solo así se nos revelan esos paradigmas que fueron construidos sobre una falsa moral religiosa que en nombre de Dios y del “bien” justificó la barbarie.

Según el filósofo de la liberación Enrique Dussel, 1492 representa el nacimiento de la Modernidad como concepto o "el proceso originario de la constitución de la subjetividad moderna” (Dussel, 1994, p. 18). Este fue el año en que el español y expedicionario Cristóbal Colón desembarcó en territorio latinoamericano por mandato de los reyes católicos, Isabel de Castilla y Fernando de Aragón, poco antes de la llegada de los portugueses a Brasil. Creyendo haber llegado a la India, Colón se encontró con un continente aparentemente inexplorado que no había sido descubierto, además habitado, según la visión de sus “descubridores”, por hombres y mujeres "bárbaros”, "desnudos" e incivilizados, los indios. 
Según la historiografía oficial, este acontecimiento produjo "el encuentro de dos mundos"1 el primero, el mundo occidental cristiano, civilizado y racional, el segundo o también llamado el nuevo mundo "inmaduro", primitivo y pagano, por lo tanto, inferior e irracional. Así las cosas, el origen de nuestra América, según la historiografía oficial, es resultado de este encuentro entre la razón y el mito, entre la civilización y lo primitivo, entre aquello que se impone y se afirma como superior y lo otro que es arrojado como inferior, lo insignificante, lo que necesita ser colonizado, transformado en su totalidad, sometido o simplemente eliminado.

Esta narrativa sobre el origen de América Latina a partir del "descubrimiento" implica el desconocimiento y la negación intencional de la existencia previa de los pueblos indígenas y sus culturas, ${ }^{2}$ quienes fueron sometidos al más sanguinario y cobarde genocidio histórico de nuestro continente. "Estas gentes de estas Indias, aunque racionales [sic] y de la misma estirpe de aquella santa arca de Noé, están hechos irracionales [sic] y bestiales por sus idolatrías, sacrificios y ceremonias infernales" (Historia General y Natural de las Indias, libro III, capítulo 60; citado en Dussel, 1994, p. 47).

Bajo estas lógicas del pensamiento eurocéntrico y su afirmación como lo históricamente racional, se inició un proceso de conquista militar y colonización.

Una vez reconocidos los territorios geográficamente, se pasaba al control de los cuerpos, de las personas: era necesario "pacificarlas” — se decía en la época-. El que establece sobre otros pueblos la dominación del mundo español (posteriormente del europeo en general) es un militar, un guerrero. El "conquistador"

1 El encuentro de dos mundos diria Dussel: "es un eufemismo que oculta la violencia y la destrucción del mundo del otro y de la otra cultura. Fue un choque, y un choque devastador, genocida, absolutamente destructor del mundo indígena" (Dussel, 1994, p. 75).

2 Sobre las culturas indigenas de América, Dussel afirma: "En un primer grado, en el caso de los clanes y tribus de pescadores, cazadores y recolectores nómadas del sur y del norte. En un segundo grado, los plantadores con aldeas de clanes, tribus y confederación de tribus (pre-urbanos), de las culturas de las cordilleras al sur y sureste del Imperio inca, hasta los amazónicos (tupi-guarani y arawaks), caribes, y las culturas del sureste, de las praderas y del suroeste del actual Estados Unidos. En un tercer grado, la 'América Nuclear' o urbana, desde Mesoamérica (de los mayas y aztecas de México y Guatemala), hasta los chibchas de Colombia y el área del Imperio inca de Ecuador a Chile y Argentina. Inmenso 'mundo' cultural que ocupaba todo el continente, que había 'descubierto' ríos, montañas, valles, praderas; que le había puesto 'nombres'; que los había incorporado a su 'mundo de la vida (Lebenswelt)' con un sentido humano pleno. No era esto un 'vacio' incivilizado y bárbaro: era un 'pleno' de humanización, historia, sentido" (Dussel, 1994, p. 120). 
es el primer hombre moderno activo, práctico, que impone su "individualidad" violenta a otras personas, al Otro. (Dussel, 1994, p. 50)

De este modo, bajo el presupuesto de la superioridad, se legitima y afirma el carácter teleológico de la invasión como un sacrificio necesario para llegar a un estado mayor de civilización, es decir, se justifica la violencia cometida hacia el otro, considerado culpable de su estado de inmadurez, es el "origen" de un "mito" de violencia sacrificial muy particular (Dussel, 1994, p. 18). Europa se afirma como juez, como centro del mundo y final de la historia y despliega una violencia sin precedentes que culmina en un aniquilamiento total de los pueblos originarios.

Vienen los españoles a cerrar las salidas, las entradas [...]. Ya nadie [de los aztecas] pudo salir. Inmediatamente los españoles entran en el patio sagrado a matar a la gente. Van de pie llevan sus escudos de madera, y algunos los llevan de metal y sus espadas. Inmediatamente cercan a los que bailan, se lanzan al lugar de los atabales, dieron un tajo al que estaba tañendo; le cortaron ambos brazos. Luego lo decapitaron; lejos fue a caer su cabeza cercenada.

Al momento todos [los españoles] acuchillan, alancean a la gente y les dan tajos, con las espadas los hieren. A algunos les acometieron por detrás; inmediatamente cayeron por tierra dispersa sus entrañas. A otros les desgarraron la cabeza; les rebanaron la cabeza enteramente desgarradas quedaron sus cabezas. A aquellos hieren en los muslos, a estos en las pantorrillas, a los demás allá en pleno abdomen. Todas las entrañas cayeron por tierra. Y había algunos que ya no corrían; iban arrastrando los intestinos y parecían enredarse los pies en ellos. Anhelosos de ponerse a salvo no hallaban a dónde dirigirse. Pues algunos intentaban salir: allí en la entrada los herían, los apuñalaban, otros escalaban los muros; pero no pudieron salvarse. (Garibay, 1994)

La invasión de América se afirmó violentamente contra toda tradición y cosmogonía de los pueblos originarios, el espíritu europeo se impuso mediante una violación y una total negación del mundo del otro, en las que imperó la exigencia de romper con una representación de mundo que se fundamentaba en el culto y la armonía con lo pretérito y la naturaleza. 
Así se establecía, por vez primera, una "relación” con el Otro, el afuera o el Extranjero absoluto que procedía como el Sol del Oriente infinito del Océano, innavegable para los mexicanos. Era lo que daría el sentido a la Nueva Edad del Mundo: la "relación" con lo Extranjero absoluto, la dominación debajo del Extranjero, divino, que venía para conquistar, dominar, matar. La primera relación entonces fue de violencia: una relación "militar" de conquistador-conquistado; de una tecnología militar desarrollada contra una tecnología militar subdesarrollada. La primera "experiencia" moderna fue de la superioridad cuasi-divina del "Yo" europeo sobre el Otro primitivo, rústico, inferior. Es un "Yo" violento militar que "codicia", que anhela riqueza, poder, gloria. (Dussel, 1994, p. 56)

Durante siglos se nos impuso la idea de la invasión o "el en-cubrimiento de América" como un total privilegio, se fueron estableciendo paradigmas que justificaban la violencia históricamente ejercida sobre los pueblos originarios y se construyeron narrativas que visaban al total aniquilamiento de las memorias de los pueblos indígenas. Hasta la actualidad, la memoria histórica de nuestras naciones continúa elogiando a los invasores. La "civilización” o "modernización” eurocéntrica usurpó, además de nuestras riquezas materiales, nuestras memorias ancestrales, nuestra América Latina, como diría Galeano, "desde temprano fue condenada a la amnesia por los que la impidieron de ser" (1986, p. 15).

De manera que los habitantes originarios de nuestras tierras vieron negadas sus creencias, sus costumbres, sus representaciones de mundo, sus dioses y sus tradiciones. Fueron condenados a sublevarse ante un dios y una razón ajena, violenta: la razón instrumental eurocéntrica. En este orden de ideas, en aras de comprender nuestra realidad actual, será necesaria la de-construcción del relato historicista sobre el pasado de nuestra América, tendremos que escuchar a quienes han padecido hasta nuestros días esa histórica dominación, o como afirma Dussel, será necesario: “Tener memoria de la víctima inocente (la mujer india, el varón dominado, la cultura autóctona) para poder afirmar de manera liberadora al mestizo, a la nueva cultura latinoamericana" (Dussel, 1994, p. 62). 


\section{Los lugares de la memoria}

En el año 1984, Pierre Nora propuso la noción de "lugares de la memoria", definida de la siguiente manera:

Son lugares con efecto en los tres sentidos de la palabra, material, simbólico y funcional, simultáneamente, solo en diferentes grados. Incluso un lugar con una apariencia puramente material, como un archivador, es solo un lugar de memoria si la imaginación lo invierte con un aura simbólica. Incluso un lugar puramente funcional, como un manual de clase, un testamento, una asociación de excombatientes, solo entra en la categoría si es objeto de un ritual. Incluso un minuto de silencio que parece ser un ejemplo extremo de un significado simbólico, es al mismo tiempo el recorte material de una unidad temporal y sirve, periódicamente, para un llamado concentrado de recuerdo. Los tres aspectos siempre coexisten. (Nora, 1993, p. 12)

En este artículo, llamaremos lugares a aquellos elementos que albergan fragmentos de lo pretérito in-visibilizado por el discurso histórico oficial y que permiten establecer un vínculo trascendente entre pasado y presente; una recreación del pasado que surge a partir de la reconstrucción interpretativa de ruinas, rastros y vestigios de un tiempo que no ha dejado de ser y al que aún es posible acceder y conocer. De esos elementos que se constituyen como lugares de la memoria hacen parte la literatura, las imágenes, los objetos, las ruinas arquitectónicas, los cantos y otras expresiones relacionadas con la tradición oral, como alternativas a una forma hegemónica de concebir el pasado en las que la experiencia del oprimido adquiere un valor significativo. De esta forma, nuestro objetivo es resaltar aquellas historias de resistencia, de sufrimiento y de verdad sobre el pasado que habitan en esos lugares.

\section{La literatura latinoamericanista de Eduardo Galeano y Pablo Neruda}

En el universo poético y literario de Galeano y Neruda tienen un lugar privilegiado las memorias latinoamericanas. En sus obras figuran las experiencias de las clases oprimidas, los desposeídos y los olvidados del continente, al igual que pensamientos y visiones de nuestro pasado que representan un vínculo místico con la tierra, las costumbres 
y la ancestralidad de los pueblos originarios. Esto da como resultado una identidad literaria en la que lo excluido y desterrado por la historia encuentra un lugar para ser y resistir la opresión y el olvido. Así, el poeta usa la poesía como arma revolucionaria, como una forma de hacer catarsis con la que encara la realidad de la injusticia mediante su palabra y abriga al que sufre en sus creaciones espirituales.

Neruda nació en Chile el 12 de julio de 1904, según Gabriel García Márquez es el más grande poeta del siglo xx, fue galardonado con el Premio Nobel de Literatura en 1971 y fue reconocido militante de distintas causas sociales. En 1969, el Partido Comunista de Chile lo nombró precandidato a presidente de la República, sin embargo, él mismo retiró su candidatura a favor de su amigo, el médico socialista Salvador Allende, quien llegó al poder en 1970. La poesía de Neruda surgió en estrecho vínculo con las realidades sociales del continente. Canto general (1950) es considerada una de sus obras más importantes, de un extraordinario contenido político, sus poemas son una apología a la naturaleza, a la historia de la América Latina y a quienes lucharon por defenderla. En el primer apartado, intitulado: "La lámpara en la tierra” sobresale un conmovedor poema “Amor América (1400)" en el que se puede apreciar una visión nostálgica por las comunidades pre-colombinas. Este poema es un canto a la memoria de nuestros ancestros vencidos, el recuerdo de una vida anterior antes de la irrupción de la barbarie civilizada moderna.

\author{
Amor América (1400) \\ Antes que la peluca y la casaca \\ fueron los ríos, ríos arteriales: \\ fueron las cordilleras, en cuya onda raída \\ el cóndor o la nieve parecían inmóviles: \\ fue la humedad y la espesura, el trueno \\ sin nombre todavía, las pampas planetarias. \\ El hombre tierra fue, vasija, párpado \\ del barro trémulo, forma de la arcilla, \\ fue cántaro caribe, piedra chibcha, \\ copa imperial o sílice araucana. \\ Tierno y sangriento fue, pero en la empuñadura \\ de su arma de cristal humedecido, \\ las iniciales de la tierra estaban \\ escritas.
}


Nadie pudo

recordarlas después: el viento

las olvidó, el idioma del agua

fue enterrado, las claves se perdieron

o se inundaron de silencio o sangre.

No se perdió la vida, hermanos pastorales.

Pero como una rosa salvaje

cayó una gota roja en la espesura

y se apagó una lámpara de tierra.

Yo estoy aquí para contar la historia.

Desde la paz del búfalo

hasta las azotadas arenas

de la tierra final, en las espumas

acumuladas de la luz antártica,

y por las madrigueras despeñadas

de la sombría paz venezolana,

te busqué, padre mío,

joven guerrero de tiniebla y cobre,

oh tú, planta nupcial, cabellera indomable,

madre caimán, metálica paloma. (Neruda, 1999, p. 2)

La vida anterior se manifiesta en la palabra y en la voz del poeta que intenta traerla hasta el presente, se trata de las memorias del hombre latinoamericano ligado a la tierra y a sus ancestros que reclaman justicia y que encuentran un lugar en el poema. La poesía se torna el lugar de la Erfahrung, siguiendo a Benjamin, una experiencia capaz de vincularse con lo pretérito para rememorarlo y comprenderlo desde el otro, el sujeto que sufre y que no obstante es quien porta la otra verdad, aquello que nos ha sido ocultado, aquello de lo que hemos sido privados. Esta poesía indignada y nostálgica cuenta la historia de una América explotada y usurpada por el invasor, "Madre de los metales, te quemaron, te mordieron, te martirizaron, te corroyeron, te pudrieron más tarde, cuando los ídolos ya no pudieron defenderte" (Neruda, 1999, p. 13).

Del mismo modo, la obra de Galeano es una aproximación a la comprensión y reconstrucción de la historia latinoamericana desde la perspectiva de los vencidos. En sus novelas y cuentos se encuentra una protesta tácita contra el colonialismo, 
las intervenciones imperialistas y las condiciones socio-políticas del continente, fundamentadas en una sólida base documental que intenta rescatar la memoria de nuestros ancestros. Galeano nació en Montevideo, Uruguay, el 3 de septiembre de 1940, fue escritor, periodista y poeta, considerado uno de los más influyentes e importantes pensadores de la izquierda latinoamericana. Dentro de sus obras más destacadas se encuentran Las venas abiertas de América Latina (1971) y Memoria del fuego (1986). Esta última, una trilogía que cuenta la historia de América Latina en forma de narrativa literaria, prosa y prosa poética.

En esta obra Galeano ilustra la tradición oral de los pueblos latinoamericanos y el origen de la invasión y la Conquista. La primera parte está conformada por una narrativa de los mitos indígenas de la América precolombina. En el segundo y tercer apartados se narra la historia de la invasión y la barbarie a partir del proceso de colonización. De la primera parte destacaremos el siguiente relato:

\section{El profeta}

Echado en la estera, boca arriba, el sacerdote-jaguar de Yucatán escuchó el mensaje de los dioses. Ellos le hablaron a través del tejado, montados a horcajadas sobre su casa, en un idioma que nadie más entendía.

Chilam Balam, el que era boca de los dioses, recordó lo que todavía no había ocurrido:

-Dispersados serán por el mundo las mujeres que cantan y los hombres que cantan y todos los que cantan... Nadie se librará nadie se salvará... Mucha miseria habrá en los años del imperio de la codicia. Los hombres, esclavos han de hacerse. Triste estará el rostro del Sol... Se despoblará el mundo, se hará pequeño y humillado. (Galeano, 1986, p. 77)

Era una hermenéutica de símbolos, de señales, en estrecho vínculo con la naturaleza, las que dotaban de sentido la cotidianidad de los pueblos originarios, la conciencia trágica azteca de alguna u otra forma advertía la barbarie. ${ }^{3}$ Galeano introduce ese lenguaje místico, relegado e indígena, para nosotros desconocido, puesto que la

3 "Y decian: ya hemos venido al tlatzompan, que es el fin del mundo, y estos que han venido son los que han de permanecer: no hay que esperar otra cosa, pues se cumple lo que nos dejaron dicho nuestros pasados" (Gerónimo de Mendieta, Historia Eclesiástica Indiana; citado en Dussel, 1994, p. 161). 
historiografía dominante se encargó de reducirlo a mera superstición. Es la otra versión de nuestra historia manifiesta como tragedia que se niega a desaparecer. En el segundo apartado sobresale un relato conmovedor que narra la experiencia de los americanos esclavizados en poder de los españoles.

\section{El sacrilegio}

Bartolomé Colón, hermano y lugarteniente de Cristóbal, asiste al incendio de carne humana.

Seis hombres estrenan el quemadero de Haití. El humo hace toser. Los seis están ardiendo por castigo y escarmiento: han hundido bajo tierra las imágenes de Cristo y la Virgen que fray Ramón Pané les había dejado para su protección y consuelo. Fray Ramón les había enseñado a orar de rodillas, a decir Avemaría y Paternoster y a invocar el nombre de Jesús ante la tentación, la lastimadura y la muerte.

Nadie les ha preguntado por qué enterraron las imágenes. Ellos esperaban que los nuevos dioses fecundaran las siembras de maíz, yuca, boniatos y frijoles.

El fuego agrega calor al calor húmedo, pegajoso, anunciador de lluvia fuerte. (Galeano, 1986, p. 90)

De este modo, la literatura y el poema se tornan parte de un compromiso ético y político del poeta con su pasado, una palabra que se transforma en voz y grito del oprimido, y que revela la barbarie oculta detrás de la escritura oficial de la historia. La poesía y la literatura se convierten en un lugar en el cual la memoria de los vencidos queda eternizada; un instante en la temporalidad continua de la barbarie en la que nos asalta el deber ético y el deseo filosófico de reconstruir lo que nos falta.

\section{La mirada del oprimido en la obra de Antonio Berni}

Antonio Berni (1905-1981) fue un importante pintor latinoamericano nacido en Argentina, cuya obra de estilo realista y surrealista retrata la miseria de los barrios proletarios y la tristeza de los pobres y marginados sociales. Este artista comprende el arte como aliado de un compromiso social de transformación. En 1928, el pintor visitó París y conoció a André Breton y Louis Aragon, lo que suscitó de manera inmediata un encuentro con el surrealismo. En la misma época conoció al filósofo marxista 


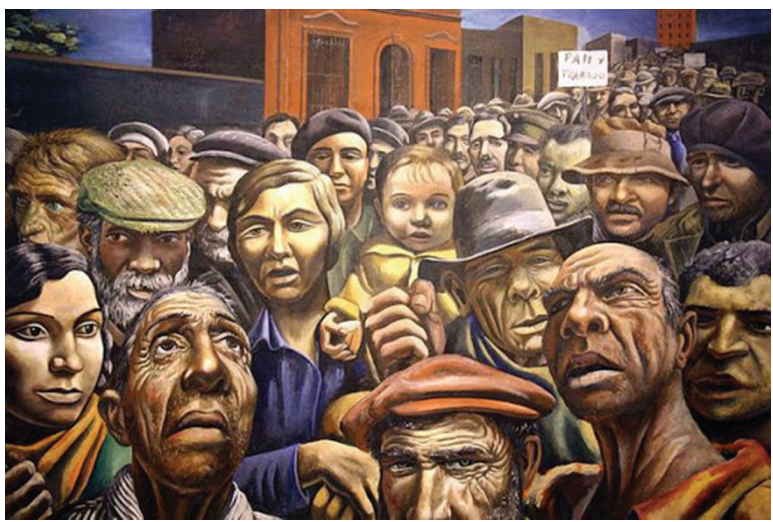

Figura1. Manifestación, Antonio Berni (1934)

Fuente: Destaques de la colección MALBA, Buenos Aires, Argentina. Recuperado de https://www.artsy.net/

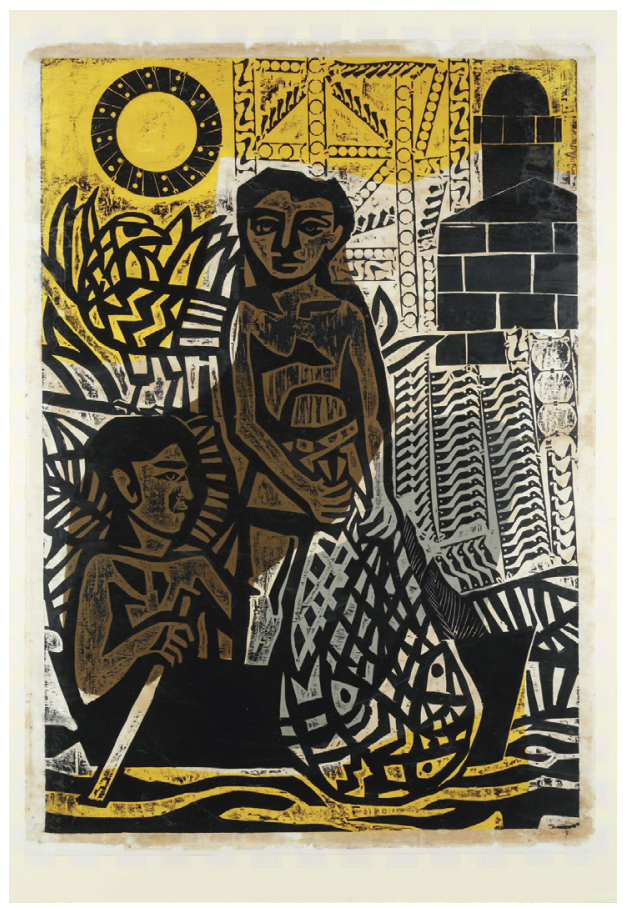

Figura 2. Juanito pescando, Antonio Berni (1961)

Fuente: Destaques de la colección malba, Buenos Aires, Argentina. Recuperado de https://www.artsy.net/ 
Henri Lefevre quien le inició en el marxismo. Posteriormente se adhirió al Partido Comunista Argentino y, bajo estas influencias, asumió el arte como un compromiso ferviente con la revolución.

Dentro de sus obras más importantes se destacan la serie de Juanito laguna, con la que Berni obtuvo el Gran Premio en la Bienal de Venecia de 1962, inspirada en los niños y niñas moradores de los barrios obreros de Buenos Aires. Berni demuestra un profundo sentido crítico y de la justicia, su pintura es una forma de dar voz a los excluidos, una herramienta para no olvidar la desigualdad histórica. Pocos días antes de morir, en una entrevista el pintor afirmo lo siguiente:

El arte es una respuesta a la vida. Ser artista es emprender una manera riesgosa de vivir, es adoptar una de las mayores formas de libertad, es no hacer concesiones. En cuanto a la pintura, es una forma de amar, de transmitir los años en el arte. (Descubrir el Arte, 2017)

\section{Ruinas y memorias en las ciudades latinoamericanas}

El concepto de ruinas es una constante en el pensamiento y obra de Benjamin. En la tesis Ix el ángel de la historia es el único capaz de divisar los escombros y las ruinas que deja a su paso el imparable avance del progreso. "En lo que para nosotros aparece como una cadena de acontecimientos, él ve una catástrofe única, que arroja a sus pies ruina sobre ruina, amontonándolas sin cesar" (Lowy, 2005, p. 87).

Así, la historia (desde la perspectiva historicista) se le presenta a Benjamin como aquello que se construye por encima de ruinas y cadáveres. Algo que se escribe y transmite como fatalidad y como destino a raíz de una concepción lineal y homogénea del tiempo que deja atrás todo lo que considera insignificante, en un movimiento de destierro y negación que lo reduce a ser solo ruina. Sin embargo, las ruinas están allí y son testimonio de un pasado y de una vida anterior que se intenta apagar. La ruina es la huella de una caída, de una interrupción, lo substituido y dejado atrás, aquello que parece no encajar en el presente pero que hace presencia en él. Es lo deteriorado y fragmentado que, sin embargo, alberga restos de un pasado capaz de hacerse cognoscible y memorable. 
La ruina abre la posibilidad de recordar pues ella inscribe la experiencia en una materialidad donde aún podemos reconocer lo sucedido. Tal como lo expresara Walter Benjamin, el concepto de "ruinas" enuncia la transitoriedad histórica a través de la desintegración y la decadencia de los pasajes pasados, mientras que por otro lado enuncia en las coordenadas del ahora, su continuidad temporal y espacial. La ruina nos dice dos cosas a la vez: por un lado, no hay retorno, solo disponemos de los fragmentos, los desechos, el polvo y las astillas de una utopía definitivamente rota. Pero, por otro lado, este punto de partida no puede dejarnos atados a la derrota por la amenaza de que el horror se repita, y de allí la invitación a crear desde esta destrucción. (Márquez, 2019, p. 6)

América Latina, desde su proceso de colonización, es un continente construido sobre las ruinas y los cadáveres de los pueblos originarios, ruinas en las que podemos encontrar horizontes de sentido a través del lenguaje mudo de las cosas. El proyecto modernizador del progreso arrasó con nuestras antiguas construcciones y cultura ancestral, sobre estas se levantaron hasta nuestros días los paisajes arquitectónicos coloniales y con ellos toda una forma de vivir y de pensar que se refleja en todos los ámbitos de nuestra existencia. No obstante, sobrevivieron algunos lugares cuya presencia evoca aquello que pudo haber sido y que quedó frustrado, por ejemplo, las ruinas de las ciudades mayas, aztecas e incas que sobrevivieron a la invasión, Tikal, Machu Picchu, Chichén Itzá y Tenochtitlán son los lugares en los que habita la historia de una barbarie y la memoria de sus víctimas.

¡Qué hermosa era Tenochtitlán, la ciudad capital de los aztecas, cuando llegó a México Cortés! Era como una mañana todo el día, y la ciudad parecía siempre como en feria. Las calles eran de agua unas, y de tierra otras; y las plazas espaciosas y muchas; y los alrededores sembrados de una gran arboleda. (Martí, 1989, pp. 306-307). ${ }^{4}$

Estos lugares guardan la memoria de nuestra catástrofe histórica, las ruinas ofrecen un lugar a lo pretérito en un presente que se manifiesta como imparable continuidad

4 "De toda aquella grandeza quedan en el museo unos cuatro vasos de oro, unas piedras como yugo, de obsidiana pulida, y uno que otro anillo labrado. jTenochtitlán no existe! No existe Tulán, la ciudad de la gran feria. No existe Texcoco, el pueblo de los palacios. Los indios de ahora, al pasar por delante de las ruinas, bajan la cabeza, mueven los labios como si dijesen algo, y mientras las ruinas no le queden atrás, no se ponen el sombrero. De ese lado de México [...], no quedó después de la Conquista una ciudad entera, ni un templo entero" (Martí, 1989, p. 308). 
de la barbarie. Una mirada hacia las ruinas nos permite detener el tiempo y encontrarnos con el pasado.

\section{Las voces contra el olvido: las alabaoras de Bojayá, Colombia}

En el corregimiento de Pogue del municipio de Bojayá, departamento del Chocó, Colombia, adquirieron un protagonismo cultural y político las mujeres a las que la tradición oral afro-chocoana denomina las alabaoras. Este término proviene del alabao, canto tradicional que el pueblo afro-chocoano interpreta en los rituales mortuorios y que es transmitido de generación en generación. En sus inicios la función del alabao era la de cantar a los muertos, despedirlos y acompañarlos en su paso hacia otros mundos. Sin embargo, a raíz del recrudecimiento del conflicto armado colombiano a mediados de la década de 1990 en las riberas del río Atrato, los alabaos se convirtieron en un escenario de resistencia política, denuncia y memoria.

En este contexto, las mujeres cumplen una función fundamental en su labor como acompañantes y líderes de los rituales tradicionales en los que a través del alabao reivindican las memorias del pueblo bojayaceño, denuncian y dan testimonio de la violencia y la injusticia que azotan a los pueblos afrocolombianos, campesinos e indígenas. A partir de la transmisión de la tradición oral estas mujeres han creado nuevos lenguajes políticos y nuevos escenarios para la creación de memoria en los que mediante el canto ritual dan testimonio del sufrimiento y recuerdan a sus víctimas y ancestros. El alabao es una forma de escribir sus historias y transmitirlas para que no sean olvidadas, una alternativa a las versiones hegemónicas sobre el pasado.

El 2 de mayo del 2002 fue una de las fechas más dolorosas para el municipio de Bojayá. En una confrontación armada entre la guerrilla de las FARC-EP y grupos paramilitares en las riberas del río Atrato, un cilindro bomba dio lugar a una masacre que dejó como saldo más de 79 muertos, de los cuales 48 eran niños y niñas. Atrapados en la iglesia del pueblo y rogando por auxilio y el cese de los disparos, sin contemplaciones y sin intervención estatal, quedaron en la memoria de los colombianos las imágenes de los cadáveres y las ruinas de aquel lamentable acontecimiento. Quienes sobrevivieron se vieron obligados a desplazarse hacia la ciudad, desconsolados, además, porque no pudieron despedir a sus muertos. 
Ante el miedo de nuevas explosiones y la continuidad del cruce de balas, la población debió huir, y este es tal vez uno de los mayores costos, pues aún se evoca con mucho dolor el que los muertos no hayan recibido los rituales debidos. (CNMH, 2010, pp. 100-101)

Ante el irreparable daño colectivo que produjeron la guerra y la ruptura del tejido social las alabaoras de Bojayá asumieron una tarea fundamental en la reparación de la comunidad, en los procesos de duelo y en la construcción de un espacio político para la preservación de la memoria y la exigencia de justicia para sus víctimas. De esta forma, el canto se constituye en un medio para resistir y combatir el miedo, un lugar para recordar a los ancestros caídos, un espacio para liberar el dolor. En estas tierras el dolor es cantado, se recuerda a los muertos y se les acompaña con música para que nunca se pierda el vínculo entre los vivos y los muertos. El canto, además, es un dispositivo útil para el cuidado, "compartir el dolor" es una manera de hacer del duelo individual un duelo colectivo (Toro, Sierra y Villamizar, 2016, p. 1).

En este sentido, el alabao de la tradición oral afro-chocoana es una forma distinta de construir la historia y la memoria de Colombia, el canto se convierte en el lugar donde los ausentes hacen presencia, el imperativo aquí es no olvidar a los muertos. El alabao funda un proyecto político de denuncia y memoria, al tiempo que rescata el sentido de la comunidad y la tradición. Así lo afirma una de las alabaoras de Bojayá:

La idea de componer me nace por las cosas, las situaciones que estamos viviendo y hemos vivido, pa' ver si con todos esos cantos, que por la radio, que por la televisión, la gente viene allá en Bellavista está filmando y así, pa’ ver si esos dolores le llegan también allá al presidente. Porque nosotros los campesinos somos los que tenemos que sufrir, somos los que pagamos los platos rotos de los actores armados, porque nosotros no tenemos el arma y nosotros somos a los que nos masacran, desplazan, entonces esas cosas no nos dejan, entonces esos dolores no nos dejan a nosotros. (Oneida Orejuela, comunicación personal, 15 de abril, 2016)

Después de la masacre, mujeres y hombres de la comunidad de Bojayá han querido mantener viva la memoria de sus víctimas y con este propósito han surgido nuevas composiciones de alabaos. De esta forma, cada 2 de mayo las alabaoras levantan sus voces y, en un acto de rememoración y duelo, le cantan a sus muertos. 


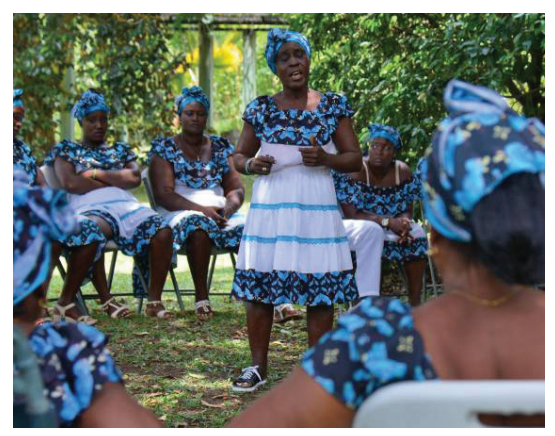

Figura 3. Alabaoras en Bojayá, Chocó, Colombia Fuente: Peláez, 28 de agosto, 2017.

El día 2 de mayo una pipeta cayó, ¡Ay!, cayó dentro de la iglesia, el cristo lo mutiló.

Esto quedó en el oscuro de la bala desplotada, como corría el agua y era sangre derramada. Esto quedó en el oscuro. (Ereiza Palomeque, 2014; citado en Riaño y Chaparro, 2016)

A manera de conclusión, este diálogo ha propuesto una reflexión crítica, en primer lugar, en torno a cómo se ha venido construyendo la historia de nuestra América desde la perspectiva del vencedor (los invasores), y cómo esta escritura y transmisión de la historia han dado lugar a una cierta legitimación de la violencia sobre las culturas originarias y a un total desconocimiento de nuestras raíces, cultura ancestral y pasado de dominación y barbarie. Esto supone una asimilación resignada de nuestra realidad actual, en la que se ha desvirtuado históricamente la verdad del oprimido y donde también se han impuesto patrones de conducta y conocimiento que desprestigian los saberes ancestrales y la tradición de nuestras comunidades. En este sentido, en correspondencia con las lecturas de Dussel y Benjamin, se hace necesaria la reconstrucción del pasado teniendo en cuenta la palabra del que padece la historia, puesto que su verdad es fundamental para la compresión y transformación de un 
presente que se nos ha impuesto como posibilidad única, y en el cual sigue vigente la continuidad de la injusticia social. Esta re-construcción de la historia supone una apertura, es decir, se manifiesta como in-determinada, repleta de nuevas versiones y posibilidades, nuevos caminos y saberes que nos conducen a una re-valorización de lo históricamente invisibilizado. Un reconocimiento y una actitud crítica frente a lo que precisa ser incluido en nuestras prácticas políticas y sociales en general.

Por otro lado, es importante abordar la compresión del pasado y la construcción de la historia más allá de la escritura y las formalidades del método histórico. Como hemos venido señalando, ante las limitaciones de la historia (historicista) surgen en nuestra América esos lugares que se rebelan como alternativa ante las narrativas hegemónicas y que nos han permitido mediante el arte y la educación conocer la realidad del otro, el oprimido y resistente sujeto latinoamericano. La poesía, la literatura, la pintura, el canto y la arquitectura han dado lugar a las memorias negadas por la historia, han dignificado a las víctimas, narran aquello que es ocultado por la historiografía oficial y nos muestran la belleza de la resistencia. Estas invaluables creaciones del sujeto latinoamericano se tornan nuestra herencia y objetos de reflexión, pequeñas irrupciones en el tiempo homogéneo y continuo que nos exigen rememoración y emancipación.

\section{Referencias}

Benjamin, W. (2020) [1928]. Marcel Brion: Bartolomé De las Casas "Padre de los indios". Buenos Aires: Buchwald.

Centro Nacional de Memoria Histórica (CNMH) (2010). Bojayá. La guerra sin límites. Bogotá: Centro Nacional de Memoria Histórica.

De las Casas, B. (2011). Brevísima relación de la destrucción de las Indias (J. M. Martínez Torrejón, ed.). Medellín: Universidad de Antioquia.

Descubrir el Arte. (10 de febrero, 2017). Antonio Berni: cronista de lo cotidiano y lo social. Recuperado de https://www.descubrirelarte.es/2017/02/10/antonio-berni-cronista-de-lo-cotidiano-y-lo-social.html

Dussel, E. (1994). El encubrimiento del otro. Hacia el origen del mito de la Modernidad. Ciudad de México: Abya-Yala. 
Galeano, E. (1986). Nascimentos. Memória do fogo I (E. Nepomuceno, trad.). Rio de Janeiro: Nova Fronteira.

Garibay, A. (1994). Siete informantes de Sahagún, Códice florentino (libro XII, cap. 20).

Lowy, M. (2005). Walter Benjamin, aviso de incêndio, uma leitura das teses sobre o conceito de história. São Paulo: Ocean Press.

Márquez, F. (2019). De ruinas y memorias en ciudades latinoamericanas. Santiago de Chile: Universidad Alberto Hurtado.

Marti, J. (1989). La Edad de Oro. La Habana: Letras Cubanas.

Nora, P. (1993). Entre memória e história: a problemática dos lugares. Projeto História, 10, 7-28.

Peláez, I. (28 de agosto, 2017). Canciones por la resistencia: las cantadoras de Pogue, Bojayá, que le cantan a la paz. El País. Recuperado de https://www.elpais.com.co/ entretenimiento/cultura/canciones-por-la-resistencia-las-cantadoras-de-poguebojaya-que-le-cantan-a-la-paz.html

Riaño-Alcalá, P. y Chaparro, R. (2016). El oficio de cantar memoria. Las musas de Pogue. Grupo de Cantadoras. Pogue, Bojayá. (Chocó-Colombia). Bogotá: The University of British Columbia, Centro Nacional de Memoria Histórica, Cocomacia.

Scholem, G. (1975). Walter Benjamin: a história de uma amizade. São Paulo: Perspectiva.

Toro, N., Sierra, M. y Villamizar, A. (2017). La política del canto y el poder de las alabaoras de Pogue (Bojayá, Chocó). Estudios Políticos, 51, 175-195.

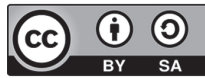

